\title{
高金利引き下げ運動にみる 大企業と市民団体の影響力
}

上川龍之進 *

\section{1 はじめに}

現代日本の圧力団体研究では，大企業と市民団体・消費者団体とは緊張 関係にあり，大企業は市民団体よりも強い政治的影響力を持つと考えられ てきた (山本 2010)。しかし, 貸金業規制をめぐる大手消費者金融会社と被 害者救済団体との対立では，長期にわたり前者の優位が続いたものの， 2006年には被害者団体が求めてきた貸出上限金利の大幅引き下げが決定さ れた。政治的影響力が弱いはずの市民団体が，いかにして大企業相手に勝 利を収めることができたのであろうか。本稿では，この事例を検討するこ とで，現代日本における大企業と市民団体の政治的影響力について新たな 知見を得ることを目的とする。

大企業と市民団体の対立を扱った事例研究としては，大獄秀夫の欠阺車 問題の研究がある (大獄 1996 ：第 2 章）1。この研究では，大企業の持つ 二次元的権力，三次元的権力が実証されるとともに，報道機関や消費者団 体，政府の批判や介入に対する企業権力の脆弱性が明らかにされた。一方

で，消費者団体兼事故被害者救済団体である「日本自動車ユーザー・ユニ オン」の運動については，マスメディアの支持を得て，一時的に自動車会 社を追い詰めたものの，市民運動の組織化は難しく，またメディアから継 続的に支持を得ることも難しいため，最終的には失敗に終わったことが示 されている。本稿では，この事例と本稿の事例とを対比しながら分析を進 め) 。

本稿の構成は以下の通りである。まず，貸金業の金利規制の歴史を追い,

* 大阪大学大学院法学研究科准教授 専攻 政治過程論 
次に，グレーゾーン金利廃止の政策過程を記述する。最後に，大手消費者 金融会社とサラ金被害者救済団体の政治的影響力について検討する。

\section{2 金利規制の歴史}

本節では，金利規制の歴史を概観する。

1877年に制定された利息制限法は1954年に改正され，制限利息は，元本 10万円未満の場合は年 $20 \%$, 元本 10 万円以上 100 万円未満の場合は年 $18 \%$, 元本 100 万円以上の場合は年15\%とされた。また 1 条 1 項では，上限金利 の超過部分は無効としているものの， 2 項では，借り手が超過部分を任意 に支払った時は返還請求できないとしている。しかもこの法律は民事法で, 違反しても刑事罰の対象とはならない。一方，同じく1954年に制定された 出資法では，制限金利は年 $109.5 \%$ と定められ，これに違反すると刑罰が科 される。そこで，いわゆる「ヤミ金融」を除く貸金業者は，利息制限法の 制限金利以上，出資法の上限金利以下の金利（いわゆる「グレーゾーン金 利」）で貸付を行っていた。

ところが最高裁判所は，1964年に，利息制限法の制限利息を超える超過 部分は元本に充当できるという判決を，1968年には，元本充当を行った結 果，過払金が生じれば，過払金の返還請求ができるという判決を出した。 最高裁が，利息制限法の 1 条 2 項を事実上死文化したのである。しかし多 くの借り手は，貸金業者との約定金利のうち利息制限法の制限利息超過部 分については支払義務がないことを知らずに，約定金利をそのまま支払っ ていた（宇都宮 2002：58-60）。

1975年頃になると，一般の消費者を対象に無担保・無保証で融資を行う 「サラ金」がマスコミに取り上げられるようになる。不況により生活資金 を補填するための利用者が増加し，店舗には行列ができるほどであった。 当時の貸金業界は「自由営業」状態で，貸金業を始めるには，大蔵省の地 方財務局や各都道府県に届け出るだけでよく, 監督官庁はなきに等しかっ た。このため, 暴力団や悪質な業者も参入した(読売新聞社会部 2003:129)。 こうした業者は年100\%近くの高金利で利用者の支払い能力を無視した過 剩融資を行い，暴力的・脅迫的な取り立てを行ったため，サラ金苦による 一家心中や自殺，夜逃げが多発した（宇都宮 2002：76）。

「サラ金地獄」が社会問題化し，マスコミも「サラ金批判キャンペーン」を 
始めた。そこで1983年に出資法が改正されるとともに，貸金業規制法が制 定された。改正出資法の本則では，上限金利は年 $40.004 \%$ とされたものの，

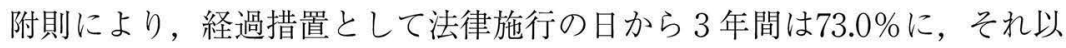
降は 54.75\%に引き下げることとされ，本則上限金利への引き下げは，法律 施行の日から 5 年が経過して以降，検討を加えて速やかに定めるとされた。 この経過措置は，当時のサラ金の貸出金利が70\%程度であることを考慮し て定められた。もっとも，この時点での消費者金融大手 3 社の貸出実効平 均金利は $45.6 \%$ であり，上限金利の引き下げは大手消費者金融会社の経営 に打撃を与えない程度に抑えられていたのである。1991年になってようや く，出資法の上限金利は $40.004 \%$ に引き下げられた。

貸金業規制法では，威迫的な取り立て行為が禁じられるなど改善がなさ れたものの，43条で「みなし弁済」規定が設けられた。この規定により， 貸金業規制法が定める17条書面（契約書面）や18条書面（受取証書）を貸 金業者が融資の際に交付するなど厳格な要件を満たし，かつ「債務者が利 息として任意に支払った」場合，グレーゾーン金利の支払いは有効とみな されることになった（読売新聞社会部 2003：130；宇都宮 2002：59-60； 菅原 2006: 1)。つまりこれは, 最高裁によって否定された利息制限法 1 条 2 項を事実上，復活させるものであった。

一方で，1970年代後半以降，サラ金被害者を支援する団体が各地で結成 されている。1978年には弁護士や司法書士らにより「全国クレジット・サ ラ金問題対策協議会」(クレサラ対協）が，1982年には各地の被害者団体の 連合体である「全国クレジット・サラ金被害者連絡協議会」（クレサラ被連 協）が結成された。また1980年 2 月には，宇都宮健児弁護士が中心となり， 東京弁護士会がサラ金問題の相談空口を開設している。こうした団体は被 害者の救済・予防活動に取り組み，そもそも利息制限法を超える金利での 貸出自体，違法との立場から，過払い金返還請求訴訟の支援も行った。し かし，これらの団体がいくら呼びかけても，高金利引き下げ運動を国民規 模に広げることはできなかった（宇都宮 2009：17, 223 ; 須田 $2006 ： 40-$ 41)。

1990年代に入るとサラ金業界は，イメージが悪化した「サラ金」ではな く「消費者金融」という呼称を用いるようになり，急速な発展を遂げる。発 展の要因としては, 第一に, 自動契約機の導入が挙げられる。1993年にア 
コムが最初に導入すると, その匿名性の高さが受け入れられ, 顧客が急速 に増加した。第二に，積極的な広告戦略が挙げられる。深夜に限られてい たテレビ CM がそれ以外の時間帯でも流されるようになり，また街角でも 従業員が大量のティッシュペーパーを配り，それまでサラ金を利用したこ とがなかった若年層や女性層の取り込みに成功した（宇都宮 2002:4-6； 堂下 2005：45-46)。第三に，大手消費者金融会社が1993年以降，次々と 株式の店頭公開に踏み切り，その後，東証一部に上場したことが挙げられ る。第四に，2002年に武富士，アコム，プロミスが，日本経済団体連合会 への加盟を果たしたことが挙げられる（堂下 2005：46-47）。消費者金融 会社はイメージアップに成功し，すっかり市民権を得たのである。

ところが，1999年に商工ローンが社会問題になることで，出資法の上限 金利引き下げの議論が再燃する2。10月21日に千葉市の男性が，脅迫まが いの取り立てを受けたとして「日栄」を相手取り，約300万円の慰謝料を求 める損害賠償請求訴訟を起こした。男性の代理人となった宇都宮は記者会 見を行い，日栄の元社員（8月で退社）が，腎臓，肝蔵，目玉を売って金 を返せと電話で怒鳴る声を録音したテープを公開した。これがテレビでセ ンセーショナルに報道されたのである。

日栄は当時，各局の報道番組で $\mathrm{CM}$ を盛んに流すことで，社会的信用を 得ようとし，さらにはテレビで告発されるのを防ごうとしていた。そこで 宇都宮らが結成していた「日栄・商工ファンド対策全国弁護団」は，民放 各局を回って CM の中止を要請したものの，相手にされなかった。ところ が，元社員が恐掲未遂容疑で逮捕されるや否や，各局は一斉に $\mathrm{CM}$ を打ち 切った（宇都宮 2009：134-143，147－148）。

この商工ローン問題は国会でも取り上げられ，その高金利にも批判の目 が向けられた。民主党は，出資法の上限金利を利息制限法の上限金利にま で引き下げるとした出資法改正案を国会に提出した。これに対し与党は, 上限金利を大幅に引き下げると中小・零細の貸金業者が倒産し，借入先を 失う利用者がヤミ金融に流れる恐㞦があるとして，グレーゾーン金利廃止 には消極的であった。しかし自民党内でも，引き下げなければ国民の理解 は得られないという意見が大勢で，結局，自民，自由，公明の与党三党は， $29.2 \%$ に引き下げることで合意した。当時の大手消費者金融会社の金利水 準は $20 \%$ 台後半であったため，与党案では金利を引き下げないで済むケー 
スが多く, 経営に打撃を与えるものではなかった（東京新聞・商工ローン 問題取材班 1999：163-165；『朝日新聞』1999年12月 3 日付朝刊）。

この出資法改正法の附則において，「出資法の上限金利については法律 施行後 3 年を経過した場合において検討を加え，必要な見直しを行うもの とする」旨の見直し規定が設けられた（菅原 2006：4）。そこで弁護士， 司法書士，サラ金被害者らが，1999年12月1日に「クレジット・サラ金・ 商工ローンの高金利引き下げを求める全国連絡会」(高金利引き下げ全国連 絡会）を結成し，宇都宮らが代表幹事に就任した。会は 3 年後の上限金利 見直しをにらんで，政党や省庁に対するロビー活動を始めた。

これに対抗して消費者金融業界も，政界工作を活発化させる。2000年11 月に「全国貸金業政治連盟」(全政連)を結成し，自民党をはじめとする与 党議員, さらに民主党議員にも，パーティー券の購入や政治家数十人を招 いた懇親会の開催を通じて資金を提供した（宇都宮 2009:212，220-221； 須田 2010：79-80)。

金利の見直し時期とされた2003年には，ヤミ金融が社会問題となってい た。貸金業者は，2000年 6 月に改正出資法が施行され上限金利が引き下げ られたためにヤミ金融が増えたと主張し，上限金利を34.675\%に引き上げ るよう求めた。これに対して被害者救済団体は, ヤミ金融が増えたのはサ ラ金の高金利が多重債務者を生み出したためだと主張し，上限金利引き下 げを求めた。自民党は議論を先送りし，上限金利は据え置かれた。ヤミ金 融対策のため 7 月に成立した改正貸金業規制法の附則には，「法改正後の 貸金業制度のあり方および出資法の上限金利については，改正法施行後 3 年を目途として，必要な見直しを行うものとする」という文言が盛り达ま れた（読売新聞社会部 2003：56-57，162-163；菅原 2006：1，9）。

貸金業界はヤミ金融対策として，上限金利引き上げにとどまらず，自由 金利論まで唱えるようになった。出資法の上限金利を撤廃し，貸金業者が 客の信用力に応じて自由に金利を設定できるようにすれば，信用力が低い 人にもリスクに見合った金利で貸し出せるようになる。そうすればヤミ金 融は客を失い，自然となくなるというのである 3 。業界の働きかけが効い たのか，自由金利論は自民党議員の間でも支持を広げた（読売新聞社会部 2003:161-162)。この主張を理論的に支えたのが，2000年に設立された早 稲田大学消費者金融サービス研究所（2010年10月 1 日よりクレジットビジ 
ネス研究所に名称変更）でここに集う学者たちが自由金利論を主張した (宇都宮 2009:220-221)。この研究所の運営は寄付を頼りとしており，大 手中堅の貸金業者11社でつくる任意団体「消費者金融サービス研究振興協 会」が，2000年度以降，毎年600万〜 700万円，2007年度までで総額5,100万 円の寄付を行っていた（三宅 2007）。

\section{3 グレーゾーン金利廃止の政策過程}

本節では，出資法の上限金利引き下げをめぐる政策過程を概観する。 2003年 4 月に 3 人の弁護士が, 武富士の過剰融資や違法な取り立て, 過 酷な社員管理などを暴露した本（武富士被害対策全国会議編『武富士の闇 を暴く』）を出版した。これに対し武富士は, 著者の弁護士と出版社に 5,500 万円の損害賠償を請求してきた。武富士は, 自社を批判した記事を 雑誌に書いたフリージャーナリスト, その記事を載せた出版社, 編集者ら に対しても，1億1,000万円，2 億円といった高額の損害賠償請求訴訟を次 々と起こしていた。宇都宮らが，訴えられた弁護士の支援に回ったところ， 武富士の元社員が内部告発をしてきた。元社員は, 創業者である武井保雄 会長から，サラ金問題を追及していたフリージャーナリストや武富士の役 員，退社した社員に対し，電話の盗聴や尾行を行うよう命じられていたと 証言し，その証拠となる内部資料や盗聴のテープを提供した。2003年 5 月 には，盗聴の被害に遭ったフリージャーナリストの山岡俊介が警視庁北沢 警察署に武井会長を告訴した。ところが，山岡の記者会見には大勢の記者 が詰めかけたにもかかわらず，大手新聞社もテレビ局も，このニュースを 全く報じなかった。6月13日には宇都宮らが内部告発に基づき, 武富士と 武井を東京地検に告発し，記者会見を行った。盗聴テープという実物があ ったためか，この記者会見は一部のニュース番組が放送し，一般紙も小さ な記事を書いた。これを受け警視庁が盗聴容疑の捜査に本格的に着手し， 12月 2 日に武井を電気通信事業法違反の容疑で逮捕した（宇都宮 2009:192 -193，198-208)。これにより, サラ金業界のイメージは再び悪化した。

他方，金融庁には，大手消費者金融会社が全国で多くのトラブルを抱え， 過払い金の返還を求める集団訴訟を起こされているという情報が寄せられ ていた。その中でも法律知識のない老人や障碍者を狙った違法行為が目立 ち，特に苦情が多く寄せられていたアイフルに対し，金融庁は2005年 5 月 
に異例の立ち入り検査を実施した（須田 2006：24-27）。

2004年 1 月に施行された改正貸金業規制法は, 施行から 3 年を目途とし て必要な見直しを行うとされていた。そこで金融庁は2005年 3 月に，総務 企画局長の私的懇談会との位置づけで「貸金業制度等に関する懇談会」(貸 金業懇談会）を発足させた。メンバーは金融審議会のメンバーでもある学 者や弁護士たちで，オブザーバーとして全国貸金業協会連合会会長やアコ 厶社長, さらに宇都宮やクレサラ被連協事務局長も入っていた(井手 2007: 25-26)。

この貸金業懇談会では，サラ金被害者の救済にあたってきた弁護士から ヒアリングを行ったものの，被害者本人から話を聞く予定はなかった（宇 都宮 2009:231）。だが，2005年 3 月に 2 年の任期付きで金融庁に採用され， 懇談会の担当となった弁護士の森雅子・信用制度参事官室課長補佐が，多 重債務者支援団体の代表を懇談会に呼ぼうとした。すると財務省から金融 庁内の別の部署に出向中の中堅幹部が森を部屋に呼びつけ，「前例のない ことをする以上，なぜそれが必要なのか一○○ページは資料を用意しろ」 と叱責した。そこで何とか資料を用意すると，その幹部は，「消費者団体の 言うことを鵜吞みにして，こんな極端な例で全体の議論をゆがめるのか」 と怒鳴って資料を床に投げつけた（井手 $2007 ： 88$ )。けれども森の尽力に より，この試みは成功し，サラ金被害者が懇談会で被害の実態を訴えた。 これは政府の審議会としては異例のことで，この招致を境に，中立派の委 員も規制強化に傾いていった4。

救済団体にとって，さらに幸運だったのは，2005年10月31日の内閣改造 で，与謝野馨が金融担当大臣に，後藤田正純が内閣府政務官（金融・経済 財政担当）に就任したことである。彼らはともに，高金利の貸金業者は規 制すべきという考えで，彼らの就任により「懇談会の議論はがらりと基調 を変え, 業界の権益よりも消費者の利益を重視するようになった」(宇都宮 $2009: 231-232$ )。

とはいえ上限金利引き下げに踏み出すきっかけとなったのは，2006年 1 月13日の最高裁判決であった。この裁判は，アイフルの子会社の商工ロー ン「シティズ」が債務者に返済を求めたもので，グレーゾーン金利の有効 性が争われていた。一審, 二審は, いずれも借り手に対して全額の支払い を認めていた。これまで貸金業者は，グレーゾーン金利の有效性が争われ 
た裁判で敗色が濃くなると, 和解を提案して敗訴を免れてきた。しかしこ の裁判では，アイフルの弁護士は勝てると考え，勝訴判決を勝ち取ろうと していた。ここで最高裁がグレーゾーン金利の有効性を認める判決を出せ ば，全国で起きている過払い金返還請求訴訟で原告側の勝ち目はほとんど なくなる。アイフルの狙いはそこにあった。

ところが最高裁の決定は，原判決を破棄し，二審へ差し戻すというもの で，事実上，シティズの敗訴が確定した。最高裁は当該融資の契約に，返 済が滞った場合には借り手に対して残りの元本と利息の一括返済を求める ことができるとする「一括請求条項」が設けられていることを理由として, グレーゾーン金利が有効とみなされるための前提である，支払いの任意性 を否定した。この条項により，支払いが少しでも滞ると利息制限法を超え る部分も含めて残額をすべて一括で支払わなければならないという誤解を 債務者に生じさせ，制限超過利息の支払いを事実上強制することになるた め，任意で支払われたとは言えなくなるというのである。そのうえで最高 裁は,「このような䛊解が生じなかったといえるような特段の事情」があっ たかどうかについて審理し直すよう，裁判を差し戻した。「一括請求条項」 は，複数の業者から借金している借り手が返済不能に陥った時に，他者に 財産を差し押さえられたり債権をすべて回収されたりする前に残額を回収 しやすくするためのもので，住宅ローンでも消費者金融でも必要不可欠と されてきた。その条項を根拠にグレーゾーン金利の有効性を否定するとい うことは，事実上，グレーゾーン金利をすべて無効とするのに等しかった。

消費者金融を担当する大森泰人・総務企画局信用制度参事官は，この判 決文から，グレーゾーン金利を制度として認めないという最高裁の強い意 志を感じ，激しい抵抗に遭うと思いつつも，出資法の上限金利を利息制限 法の水準にまで引き下げる形でのグレーゾーン金利廃止に取り組むことを 決意した（井手 $2007 ： 15,21-22,24-27$ ）。

一方で，高金利引き下げ全国連絡会は，2007年に予定される上限金利見 直しに向けて動いていた。2005年 2 月26日には東京で決起集会を開き，高 金利の引き下げを求める100万人の署名活動を呼びかけた。しかし，呼び かけを行った宇都宮自身, 従来の勢力のみでは, とても100万人という目標 は達成できないと思っていた。

ところが宇都宮に対して, 労働者福祉中央協議会（中央労福協）が金利 
引き下げ運動に関心を持っており，クレジット・サラ金の金利問題に取り 組む組織をつくるので，代表世話人になってほしいという話が持ち込まれ た 5 。宇都宮は, 中央労福協が呼びかければ連合も動き出すと考光，その 申し入れを即諾した。中央労福協と宇都宮が呼びかけ人となって, 2005年 12月 7 日に「クレ・サラ金利問題を考える連絡会議」(連絡会議) が発足し， メンバーとして弁護士や司法書士，連合や労金協会の代表，さらに消費者 団体や生協が加わった。これにより金利引き下げ運動のネットワークは飛 躍的に広がった。

2006年 3 月 4 日には，高金利引き下げ全国連絡会と連絡会議，中央労福 協の共催，全国消費者団体連絡会の後援により，「高金利引き下げをめざす 全国集会——多重債務社会を打ち破ろう！」と題した集会が開かれ，弁護 士，司法書士，学者，被害者救済団体，労働団体，消費者団体の関倸者ら 570 人以上が集まった。さらに集会後には, 霞が関から東京駅まで, 連合の 街宣車を先頭にデモ行進を行った。これは初めての試みで, 以後, 全国的 な集会の後には必ずデモ行進を行うようになった（宇都宮 2009:223-226)。 5 月18日には中央労福協と連絡会議の呼びかけにより, 参議院議員会館で 「貸金業のグレーゾーン撤廃と高金利引き下げを実現する国民代表者集会」 が開かれた。この集会には自民・民主・公明・共産・社民・国民新党の中 堅クラスの議員が集まり, 前連合会長の笹森清・中央労福協会長も演壇に 立った（宇都宮 $2009: 226$; 井手 $2007: 84-85$ )。

中央労福協との協力の成果は，署名活動でも顕著に現れた。高金利引き 下げ全国連絡会が呼びかけた上限金利引き下げの署名は，10月11日に国会 に提出された。集まった署名は当初の想定を大幅に上回る340万955筆に上 り，団体ごとの内訳は，中央労福協が286万 8,273 筆，高金利引き下げ全国 連絡会が29万8,495筆，日弁連が23万4,187筆で，労働組合の組織力を見せ つけた（宇都宮 $2009 ： 227-228$ )。

一方，貸金業懇談会では 4 月18日に中間報告の原案発表を，21日にとり まとめを行う予定であった。これに先立ち大森は，中立派と見られていた 委員数人に根回しを行った。さらに 4 月 14 日に金融庁は，違法な取り立て 行為や認知症の疑いが濃い老人への貸付などで前年から問題となっていた アイフルに対し，厳しい行政処分を発表した。アイフル本社所在地の京都 を管轄する近畿財務局は，2005年から聞き取り調査に着手していたものの， 
大手消費者金融会社への処分はあまり前例がないこともあり，大規模な処 分には及び腰であった。ところが，2006年初めに近畿財務局の貸金業担当 者を集めた会議で，金融庁金融会社室長が動きの鈍い担当者を一掲したた め, 近畿財務局は処分に向け急速に調査を進め，様々な内容の違法行為を 確認したのである。

貸金業懇談会の雲囲気は，この処分によって一变した。ある自民党代議 士秘書は，「あの処分さえなければもっと業界の言い分を踏まえた発言も できたが，あのおかげで業界寄りの発言は選挙対策上，一切タブーという 雲囲気が出来上がってしまった」と証言している。18日に懇談会に提出さ れた中間報告書の原案では, 出資法の上限金利引き下げが明記された（井 手 2007:63-71)。

けれども実のところ，金融庁は中間報告では単なる両論併記で終わらせ るつもりであった。貸金業規制法はもともと議員立法であるため，これま で改正は議員立法で行われており，この時の法改正も当初は議員立法を想 定していた。すでに 3 月末の時点で自民党は, 金融調査会 (金子一義会長) の下に「貸金業制度等に関する小委員会」を設置しており，大蔵省 OB の 増原義剛衆議院議員が委員長に就任していた。金融調査会の幹部たちは, 出資法の上限金利を利息制限法の水準にまで引き下げることは考えていな かった。

ところが，金融庁上層部が中間報告を両論併記にとどめようとしている ことを知った森が，引き下げ方針を明記するよう後藤田に進言した。後藤 田は三國谷勝範・総務企画局長を政務官室に呼び出し，その場で与謝野に 電話をかけた。与謝野は，後藤田の要請を受け入れ，中間報告で上限金利 引き下げの方針を打ち出すことを了承した。大森は，それでは金子や増原 を追い达んでしまうことになると反対したものの，後藤田は応じなかった。 この結果，議員立法と想定されていた貸金業規制法改正案の最も重大な部 分について官庁が方向性を決めるという「霞が関の常識では考えられない ことが起き」た。増原は，「こうやって中間報告に書かれた以上，それに反 対したら俺たち（自民党）は抵抗勢力か」とぼやいた（井手 2007：72$74,80-81)$ 。

上限金利引き下げは見送られるか,引き下げられたとしても25\%程度ま でだろうと考えていた消費者金融業界は，懇談会の中間報告に猛反発した。 
だが，法改正は議員立法で行われる予定だったため，消費者金融業界は自 民党内での議論に期待をかけた。小委員会は 5 月11日に初会合を開き，そ の場で保岡興治，太田誠一といったべテラン議員たちが上限金利引き下げ への反対論を主張した。それに対し，大塚拓，木原稳といった当選 1 回の 若手議員たちは，上限金利の引き下げを主張し，両者は激しく対立した(井 手 $2007: 74-75,83-84$ )。

小委員会には，議員以外の関係者も比較的自由に出席できたため，全国 貸金業協会連合会や全国銀行協会といった業界団体も議論に加わり，宇都 宮たちも日弁連を代表して每回出席した。初めのうちは，業界の意向を受 けた議員たちが毎回出席するのに対し，金利引き下げに賛成する議員たち は出席してまで意見を述べようとはしなかった。そこで宇都宮らは，金利 問題にあまり関心がない議員に対しても，多重債務の被害の実態を説明し， 根本的な解決には金利を引き下げるしかないと訴え，小委員会に出席する よう働きかけた。その結果，若手議員たちが出席して金利引き下げを主張 するようになったのである（宇都宮 2009：232-233）。

金利引き下げを求める団体が自民党議員へのロビー活動を円滑に行えた のは，日弁連の力によるところが大きい。宇都宮らは，金利引き下げ運動 を日弁連全体で推し進めようと考え，対策本部の設置を求める意見書を提 出した。日并連では，ある課題について対策本部をつくる場合，会長が本 部長を務め, 理事も全員, 対策本部の委員に就く。対策本部の決定は, 地 方の弁護士会の会長でもある理事を通じて全国の弁護士に伝えられる。さ らに対策本部には特別に予算が組まれるため，機動的な対応が可能になる。 執行部は2006年 2 月 16 日に「上限金利引き下げ実現本部」(実現本部)を設 置することを決め，実務を仕切る本部長代行に宇都宫が就任した。

これ以降，実現本部が中心となって，政党や議員への働きかけを行った。 それまでは連合が政治家へのロビー活動を行っていたのだが，民主党寄り である連合を自民党はあまり相手にしない。しかし，日弁連の要請は聞く。 そこで実現本部は各地の弁護士会に，地元出身の自民党議員へ働きかける よう依頼し，最終的には自民党のほほすすへてての議員に金利引き下げの要望 を伝えた（宇都宮 $2009 ： 228-229$ )。

金利引き下げ賛成派と反対派の対立は激しくなる一方であった。しかし 7 月 5 日に増原は,「グレーゾーン金利廃止後の金利体系については, 出資 
法の上限金利を利息制限法の金利水準に引き下げることを基本として，必 要な検討を進めることが適当である」という結論を記した報告書を発表し た。中川秀直政調会長の「それでいいんじゃないか」という一言が決め手 になった。ただし報告書では，利息制限法の金額区分の引き上げや，少額・ 短期の貸付について特例で高金利を認めることの是非について，金融庁に 検討するよう求めていた。これを受けて金融庁が，具体的な制度設計を行 うことになった（井手 2007 : 90-93）。

金融庁は，金利の引き下げで信用力の低い借り手が融資を受けられなく なり，ヤミ金融被害が増えるという副作用を避けるため，また金利引き下 げに反対する議員の顔を立て，法案を円滑に通すため（井手 $2007 ： 119$ 120)，少額・短期の貸付については 5 年間の時限措置として例外的に高金 利を認める特例措置を導入することにした。また利息制限法が最後に改正 された1954年以来，5倍強になっている物価上昇を考慮し，利息制限法の 金額区分を 5 倍の50万円，500万円に引き上げることにした(大森 2007:240 -243）。懇談会の委員たちは，こうした案に強く反対したものの，金融庁 は 8 月28日に金融調查会長ら少数の自民党議員に対し，特例措置と金額区 分引き上げを含めた素案を非公式に提出する。

宇都宮は 8 月30日に記者会見を開き，特例案を強く批判した。9月 6 日 には後藤田が，特例案を批判して内閣府政務官を辞任する。後藤田は記者 会見を開いて金融庁を強く批判した。新聞・テレビの大半は後藤田の辞任 を好意的に扱い，みのもんたも朝の情報番組で特例措置を強く批判した。 このため，金融庁には「業界の圧力に屈したのか」という抗議の電話が殺 到し，自民党幹部が，「みのもんたにも分かる案を作ってくれ」と金融庁に 要請するほどであった。その一方で，金利引き下げ反対派の議員たちは再 び反対論を強めた。特例措置の導入で早期決着を図ろうとする金融庁の作 戦は失敗したのである（井手 $2007 ： 117-119,123-127,133-139,142$ $-143)$ 。

しかし 9 月15日午前の金融調査会幹部会で，中川政調会長による党内調 整の結果を踏まえた特例金利や，その適用期間が示され，午後の金融調査 会・法務部会の合同会議に諮ることで合意がなされた。合同会議では依然 として意見の対立が続いたものの，これ以上議論を長引かせて党内の不一 致をさらけ出すよりは執行部の面子を立てて先に進むべきという需囲気に 
なり，金子と増原は，ようやく執行部への一任をとりつけた。結局，特例

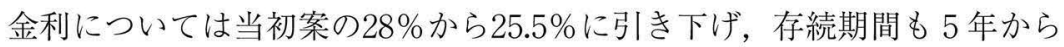
2 年に短縮し，適用対象は 30 万円・ 1 年以内，事業者向けは 500 万円 3 力 月以内とされた。また上限金利引き下げの期間については，交付から施行 まで 1 年，施行から引き下げまで 3 年という当初案を改め, 合わせて 3 年 以内とすること，この期間内に特例の必要性の有無について見直すことと した。利息制限法の金額区分については，当初案通り，それぞれ 5 倍に引 き上げることにした（井手 $2007 ： 148-150$ )。19日に自民党政調会が最終 合意を承認し，この案を基に，金融庁は法案作成作業に入った。

けれども金利引き下げを求める団体は，まだあきらめてはいなかった。 10月11日に，金利引き下げを求める署名340万955筆が国会に提出され，そ の後，参議院議員会館で「サラ金の高金利引き下げを実現する国民代表者 集会」が開かれた。自民党，公明党を除く各党の議員のほか，連合の高木 剛会長，連合傘下の労働組合員，弁護士，司法書士，被害者代表ら約200人 が集まり，例外なき金利引き下げを訴えた。この集会では，43都道府県， 1,136市町村が，金利引き下げを国に求める決議を採択したことも報告さ れた。もともとは全国青年司法書士協議会が全国の地方議会に対して，金 利引き下げを国に求める意見書を採択するよう働きかける運動を行ってい た。この運動に労福協や連合の地方組織が加わることで， 6 月から 9 月に かけて各地の地方議会で採択の動きが一気に加速したのである。

さらに10月17日には実現本部の呼びかけにより，日比谷野外音楽堂にて 「高金利引き下げ総決起集会」が開催される。1000人を想定していた参加 者は, 2000人に達した。集会後に参加者たちは, 連合の街宣車に先導され， 霞が関から国会議事堂までデモ行進を行った。議員面会所では, 多くの野 党議員に加え，10人以上の公明党議員も待ち受け，陳情書を受け取った。 その後, 衆議院議員会館で行われた集会では, 自民党も含めた各党の議員 が挨拶を行った（宇都宮 $2009 ： 227-228 ， 230 ， 237-238$ )。

ここで特例案は, 突如として撤回される。幹事長となった中川は, 佐藤 栄佐久知事が公共事業での談合事件で辞職したことに伴う福島県知事選挙 に，自民党からの出馬を要請するため，10月 5 日に森雅子と面会した。こ の場で森は，特例措置と利息制限法の金額区分変更を撤回するよう強く要 請した。この後，中川と金子，増原は，極秘毫に会合を重ねた。10月23日 
に金子と増原は，公明党幹部，金融庁幹部，法務省幹部らと極秘に会談し， 特例措置と利息制限法の金額区分引き上げを撤回することを決めた。10月 25日に自民党は合同会議で修正案を了承した（井手 2007：155-158）。

12月13日の参議院本会議で，内閣が提出した「貸金業法」が全会一致で 可決，成立した。2010年 6 月18日に，総量規制，みなし弁済制度の廃止， 出資法の上限金利引き下げなどが施行された。

\section{4 分析}

本節では，大手消費者金融会社とサラ金被害者救済団体の政治的影響力 について検討する。

\section{（1）大手消費者金融会社}

大手消費者金融会社の政治的影響力は，一見するところ，かなり強かっ たように思われる。企業のリソースとして真っ先に思い浮かぶのは, (1)政 治資金である。また欠陷車問題の事例研究では，自動車会社のリソースと して, (2)情報と専門知識の独占的利用, (3)報道機関への対抗手段の保有(優 秀な顧問弁護士，新聞・テレビの広告スポンサーになっていること), (4)大 学の研究者との関係, (5)官庁の保護, が挙げられている（大嶽 1996:4051)。それぞれのリソースについて検討してみよう。

第一に，大手消費者金融会社は積極的に政治資金を提供していた。全政 連は2003年から2005年までの 3 年間に，自民党・公明党の国会議員や政党 支部に約1,950万円の政治資金を提供している（井手 2007：87）。その甲斐 あってか一部の自民党議員は，上限金利引き下げに強く反対した 6 。

しかし最終的には，マスコミ・世論のサラ金批判に押されて，上限金利 引き下げが実現された。政治家にとっては次の選挙での当選が最優先であ り，政治資金はそのための手段に過ざない。であるから有権者が金利引き 下げを強く求めている場合, 政治献金を目的としてサラ金を擁護し続ける ことは，業界と特に親しい一部の政治家を除いては，難しいことである。 政治資金だけで業界利益を守ることには限界があった。

第二に，情報と専門知識であるが，これは借り手に対して行使された。 1968年の最高裁判決にもかかわらず，ほとんどの借り手は制限利息超過部 分については支払義務がないことを知らず，それを支払い続けた。グレー 
ゾーン金利が容認された1983年以降であっても，法で定められた要件を満 たしていないため制限利息超過部分を支払う必要がない場合も多かった。 このことは，債務者の相談に乗っていた弁護士たちには広く知られており， 2006年の最高裁判決以前にも，過払い金返還請求訴訟は全国で起こされて いた。専門知識を有した弁護士に対しては，消費者金融会社の影響力には 限界があった。しかし消費者金融会社は，敗色が濃くなると和解を提案し て敗訴を免れることで「紛争の抑圧」に成功していた。そして専門知識の ない借り手には，高金利の支払いを強要し，ほとんどの借り手は言われる ままに支払っていた。三次元的権力が行使されていたのである。

第三に，消費者金融会社も優秀な顧問弁護士をつけていた。こうした弁 護士の存在は，過払い金返還訴訟でも，またマスコミのサラ金批判を率制 するうえでも，一定の役割を果たした。実際に武富士は，自社を批判した ジャーナリストや出版社に対し, 高額の損害賠償請求訴訟を起こすことで, 批判を封じ込めようとした。

また消費者金融会社は，積極的にテレビ $\mathrm{CM}$ を流すことで，企業イメー ジを向上させると同時に，報道機関に対して影響力を持つことになった。 サラ金批判運動は，長期にわたりマスコミで取り上げられることはなかっ たし，宇都宮らが日栄の CM を中止するようテレビ局に要請しても相手に されず，武富士会長に盗聴されたと告発したジャーナリストの記者会見は 報道されなかった。二次元的権力が行使されていたのである。

しかし，「腎臓，目玉を売れ」という録音テープが公開されたり，武富士 会長が逮捕されたり，金融庁がサラ金会社の違法行為を認定して行政処分 を行ったりすると，これまで見て見好りをしてきたマスコミも，一転， サラ金バッシングを開始する。新聞社にとって重要なのは購買部数であり, 購買部数が増えるほど, 購読料が増え, 広告も集まってくる。テレビ局に とって重要なのは視聴率であり, 視聴率が上がれば, 広告料は上がり, ス ポンサーも増える。そのため，たとえ重要なスポンサーを失扔うとも，世 間が関心を持つ事件を報道しないわけにはいかないし，世論の非難が集ま る企業や業界を擁護することは難しい。それゆえ，サラ金に世間の批判が 向いていない時には，いくら被害者団体が働きかけようとも，その問題性 を報道しようとはしないのだが，世間の関心が集まるや否や，大量の批判 報道を展開するようになるのである。 
第四に, 消費者金融業界は理論武装のために学界の力も借りていた。早 稲田大学消費者金融サービス研究所に集った研究者たちが主張した自由金 利論は，一部の政治家や経済学者・エコノミストなどにも取り上げられ， 一定の影響力を持った。

しかし，マスコミがサラ金批判を始めると，こうした「学術的な」主張 が顧みられることはほとんどなくなる。学者の専門的な主張は, 専門家の 間では一定の影響力を持つのだが，世論を巻き込んでの論争となると，あ まり影響力を持てないのである。

第五に, 官庁の保護である。大訔は, 官庁が自動車会社を擁護するのは, 国益に貢献している産業に対する批判は国益を損なうものだという観点に よるものであり，企業の官庁に対する政治的影響力ではないとする。その ためマスコミの批判が開始されると, 官庁は自動車会社の擁護をやめ, 責 任を押しつけようとした。しかし，長期的に見れば機能的協力関係は存続 するのであり，世論の批判が収まれば，官庁が再び企業を保護することが 期待できたという（大獄 1996：48一-51）。

ところが金融当局には，サラ金業界を保護する誘因はそしかった。とい うのも，かねてより金融当局は消費者金融を，それほど大事な業界だとは 考えていなかったからである。1983年の貸金業規制法制定の際には，大蔵 省, 法務省, 通産省, 警察庁など関係省庁の担当者が集まり, 新法作成の 協議を始めた。しかし，各省庁は主導権をとろうとはせず押し付け合いと なり，最終的には議員立法に委ねられた（読売新聞社会部 2003:129-131）。 どの省庁も貸金業界という厄介な業界に深く関わることを嫌ったためたと 推測される。

また大蔵省内部では「金融機関＝銀行」，「融資＝大企業向け」という考 え方が強く，「なぜ，貸金業者の面倒を我々が見なければならないのか」と いう声も少なくなかったというし（読売新聞社会部 $2003: 129-131$ ), 当 時から今に至るまで, 金融当局には「消費者金融は銀行にやらせるべきだ」 という信念があったともいう（井手 2007：77-78）。このことからして， 金融当局が世間からの批判を覚悟してまでサラ金業界を擁護するとは考元 にくい。

ところが消費者金融業界は，官庁に対して別の方式で影響力を持つこと ができた。天下りポストの提供によってである。1980年以降，旧大蔵省・ 
財務省から消費者金融大手 5 社に 23 人が役員 - 顧問として天下っており, 2006年10月の時点でも 5 人の元大蔵官僚が会長や監査役に就いていた（井 手 2007:87)。このため旧大蔵省幹部の中には, 消費者金融業界を擁護する 者もいた。多重債務者支援団体の代表を貸金業懇談会に呼ぼうとした森を 叱責した中堅幹部は，その典型例であろう。

しかしながら，財務省に戻ることのない金融庁職員の意識は，大蔵省時 代とは大きく異なっていた。大蔵省と金融業界との癒着により不良債権問 題への対応に失敗したという認識から金融庁が設置され，金融庁職員の金 融業界への天下りは厳しく規制された。金融庁に移った職員たちは，金融 機関への検査・監督を睱格に行い，違法行為は厳格に処罰するなど，金融 機関に厳しい姿勢を打ち出すことで世論の支持を得ていた。金融当局は, 業者育成重視ではなく消費者保護重視へと政策志向を大きく転換させてい たのである（上川 2011）。このためグレーゾーン金利を否定する最高裁判 決が出されると，すぐに出資法の上限金利引き下げによるグレーゾーン金 利撤廃の方針が決められた。さらに金融庁は，その実現のため，貸金業懇 談会でサラ金被害者の話を聞くなど被害者団体と協力したり，大手サラ金 会社の違法行為を厳格に処分してマスコミ・世論のサラ金批判を燗ったり した。

要するに消費者金融会社が敗れた最大の要因は，監督官庁である金融庁 が業界を保護するどころか，むしろ率先して業界を潰しにかかったことに あった。これは自動車産業とは異なり規制産業である金融業では, 所管省 庁の判断次第で事業活動ができなくなるという事情にもよる（高橋 2012 ： 299）。このように規制に対して脆弱な産業であるにもかかわらず，サラ金 業界は政治家との関係構築には熱心であったものの，金融庁に対しては， そうした努力が不十分であった。もちろん金融庁の側も，大蔵省時代の反 省から，業界とは緊密な関係を持たないようにしていたし，特に厄介な業 界である貸金業界とは，あまり緊密な関係を持ちたくないとも考えていた。

結局のところ，大企業が政治的影響力を持つには，組織的リソースだけ では不十分で，監督官庁と円滑な関係を築くことが重要なのである。大企 業は情報収集や政策要求のために所管官庁と日常的に接触していること (いわゆる「政策渉外」）が指摘されているが（高橋 2012），所管官庁と円 滑な関係を築くこと自体，大企業にとっては重要で，特に規制産業にとっ 
ては決定的に重要なのである7。

これまで見てきたように大手消費者金融会社は一定の政治的影響力を有 しており，長期にわたって紛争の抑圧に成功してきた。しかしながら，そ の影響力には限界があった。大获によると，企業は「社会にとって有用な 価值を生産し，流通させ，また多くの職を提供するといった経済的機能を 果すことによって」,「自己の存在理由を社会に承認させ」,「その権力を正 当化している」。「それ故，企業の反社会性が，その有用性をこえてまで大 きくなったと判断される場合には」，「企業権力の存在そのものへの攻撃が 大々的に展開される」。この「政治化状況において双方のリソースの動員 が徹底して行われれば，権力関係のバランスは企業に不利な方へ大きく傾 くことになろう。消費者や大衆のリソースは潜在的には企業のそれにくら べて圧倒的に大きいからである」（大获 1996:60-61）。消費者金融を襲っ たのは，まさにこの事態である。そして消費者金融業界の反社会性を世間 に知らしめたのは，その違法行為を厳格に処分した金融庁であった。とこ ろが金融庁は，マスコミ・世論を最後までコントロールできたわけではな かった。特例措置や利息制限法の金額区分引き上げを実施しようとした金 融庁は，サラ金の味方として批判され，そうした措置は撤回される。これ は直接的には森が中川に要請した結果である。しかしその背景にはサラ金 の徹底規制を求めるマスコミ・世論の力があり，それを盛り上げたのは市 民団体であった。

\section{（2）サラ金被害者救済団体}

サラ金被害者救済団体が上限金利引き下げに成功した要因としては，(1) マスコミを通じた世論の支持の獲得，(2)裁判の利用，(3)他の団体との協力， (4)官庁との協力, (5)運動の長期的継続, が挙げられる。一方,「日本自動車 ユーザー・ユニオン」は, マスコミを通じて世論の支持を獲得することに 一時的に成功したものの, 財政逼迫のため長期的に運動を継続することが できず，裁判を最後まで戦い抜くこともできなかった（大訔 1996:36－40）。 また他の団体との協力も見られなかったのである。

救済団体の成功要因を検討していこう。第一に，マスコミを通じて世論 の支持を獲得したことが挙げられる。救済団体は長期にわたり世論の支持 を得られなかった。というのも一般の人々は, サラ金と関わる機会があま 
りないし，「借りた金は返すのが当然」という意識も強いため, サラ金問題 に継続的に強い関心を持つことはない。そのため1980年代にサラ金地獄が 社会問題となり，世論の後押しによって規制強化が実現されたものの，そ の後，サラ金問題は急速に忘れ去られた。

しかし宇都宮らは，日栄社員の脅迫的な取り立てや，武富士会長による 盗聴など，衝撃的なニュースを記者会見で公開することで，マスコミ・世 論の貸金業批判を盛り上げることに成功した。また上限金利引き下げ問題 でも，その必要性や特例措置の撤回を訴え，マスコミ・世論の支持をとり つけるのに成功した。

第二に，救済団体に参加した弁護士たちは，過払い金返還訴訟を全国で 起こした。粘り強く裁判に訴え続けた結果，最高裁からグレーゾーン金利 を否定する判決を勝ち取り，上限金利引き下げを金融庁が決意するきっか けをつくったのである。

第三に，他団体との協力により，効果的なロビイング活動が可能になっ た。救済団体は中央労福協を通じて連合と協力することで，デモ行進を行 ったり，大量の署名を集めたり，大規模集会を行ったりすることが可能に なった。また連合の地方組織の協力を得ることで，全国青年司法書士協議 会の意見書採択運動は成功した。さらに日弁連の協力によって, 自民党議 員へのロビイングが円滑に行えるようになった。このことが自民若手議員 の頑張りを生み，自民党が上限金利引き下げを認める結果につながった。

第四に，貸金業懇談会に宇都宮らが出席し，説得力のある議論を行った こと, 森の尽力により貸金業懇談会に出席した被害者たちの訴えが懇談会 の中立派委員の心を動かしたことも重要であった。上限金利引き下げを決 断した金融庁が市民団体を利用したわけだが，市民団体が「政治的機会構 造」をうまく活用したとも言える8。

第五に，運動を長期的に継続することに成功したことが挙げられる。 「日本自動車ユーザー・ユニオン」の失敗の最大の原因としては, 安定した 財政基盤を欠き，長期的に活動を維持することが困難であったことが挙げ られる（大获 1996：55-56）。それに対して救済団体は，1980年前後に結 成されて以降，長期にわたり運動を継続してきた。これが可能であったの は，サラ金問題を専門にする弁護士が一定の収入を得ることができたから である。宇都宮がサラ金を専門とする弁護士として開業した時には，サラ 
金問題を担当しょうとする弁護士はほとんどいなかった。サラ金被害者の 相談に乗っても弁護士費用がとれないのではないかと思われていたからで ある。そこで宇都宮は，「どうすればサラ金被害者から弁護士費用をもら えるのか」という講演を開き，弁護士費用はこれまで一括払いが当然だっ たけれども，分割払いを認め，多数のサラ金被害者から長期にわたり少し ずつ支払ってもらえば, 安定した収入となり, 事務所の経営も成り立つと 解説した。この講演以降，サラ金相談を担当する弁護士は急増した（宇都 宮 2009:22-24)。つまり欠陥車問題と比べ, サラ金の方が被害者数は格段 に多く，しかも被害者がサラ金の厳しい取り立てを免れるには個別に弁護 士に依頼しなければならないため, 被害者団体に入るかどうかはともかく, 弁護士にお金を支払うという点では，フリーライダー問題は生じなかった。 このため, サラ金専門の弁護士は安定した収入を得ることができ，被害者 救済運動を継続して行うことが可能になった。消費者金融業界は被害者を 増やし過ぎたがゆえに，世論や裁判官の反感を買っただけではなく，敵の 懷も豊かにしてしまったのである。

（1）旧版は1979年に公刊されている。本稿では増補新版（大訔 1996）を参 照した。

（2）商工ローンとは，中小・零細事業の経営者相手に連帯保証人の提供を 条件として, 手形貸付の形で数十万円台から五千万円くらいまでの融資を 行う貸金業者の総称である。

（3）自由金利論に対しては，金利を自由化すると高金利に歯止めがかから なくなる，多重債務者など高リスク層には市場原理が働かないため，一定 の上限金利により保護する必要があるといった反論がなされた（菅原 $2006: 9)$ 。

（4）森はグレーゾーン金利の撤廃に強い意欲を燃やしていた。中学生の時, 大叔父の保証人となった父親が借金の取り立てに遭い, 娘を売り飛ばすと 脅されたため, 学校にも行けない日々を過ごしたからである（井手 2009： $27-30$ ；朝日新聞』2009年12月15日付夕刊）。

（5）中央労福協は，連合やその傘下の加盟組合などの労働団体や，各地の 連合系組合と連携している地方労福協(都道府県ごとの労働者福祉協議会), 全国労働金庫協会（労金協会)，全国労働者共済生活協同組合連合会 (全 労災）など労働者福祉に関わる事業団体，さらに日本生活協同組合連合会 などにより構成されている勤労者福祉活動のための中央組織である。 
（6）選挙の際に自民党の票集めをさせられたという武富士元社員の証言も ある（須田 $2010 ： 79 ） 。$ 選挙への社員の動員も, 大企業のリソースのひと つである (早川・内海・田丸・大山 $2004: 39) 。$

（7）もっとも本事例では，消費者金融に厳しい態度をとる政治家が大臣， 政務官に就き，消費者金融に厳しい態度をとる弁護士が任期付きの担当職 員に就いていたという偶然の要因も大きい。本事例はゴミ缶モデルにより 説明可能である。

（8）一方で救済団体は，金融庁が特例措置を導入しようとした時には強硬 に反対し，その撤回を実現させてもいる。

\section{参考文献}

井手壮平 (2007)『サラ金崩壞——グレーゾーン金利撤廃をめぐる300日戦争』 早川書房。

宇都宮健児（2002）『消費者金融——実態と救済』岩波書店。

——(2009）『弁護士，闘う一一宇都宮健児の事件帖』岩波書店。

大嶽秀夫（1996）『増補新版 現代日本の政治権力経済権力——政治におけ る企業・業界・財界』三一書房。

大森泰人 (2007)『金融システムを考える—ひとつの行政現場から』社団 法人金融財政事情研究会。

上川龍之進（2011）「金融ガバナンス」大山耕輔編著『比較ガバナンス』お うふう，119-226頁。

菅原房恵（2006）「貸金業制度の現状と見直しの動き—法制度の変遷と上

限金利規制をめぐる議論」『調查と情報』第524号（国立国会図書館 ISSUE

BRIEF NUMBER 524 (MAR. 24. 2006))。

須田慎一郎（2006）『下流喰い一一消費者金融の実態』筑摩書房。

— (2010)『サラ金殲滅』宝島社。

高橋洋 (2012)「大企業から見た政治主導——政権交代による政策渉外の变容」

御厨貴編『「政治主導」の教訓——政権交代は何をもたらしたのか』勁草

書房, 289-312頁。

東京新聞・商エローン問題取材班（1999）『商工ローン 地獄への落とし穴』 リム出版新社。

堂下浩（2005）『消費者金融市場の研究——競争市場下での参入と撤退に関 する考察』文貪堂。

早川純貴 - 内海麻利 ・田丸大 · 大山礼子 (2004)『政策過程論一一政策科

学」への招待』学陽書房。

三宅勝久 (2007)「早稲田大, サラ金業界と瘾着 寄付 5 千万円で “御用論 文”量産」My News Japan ホームページ (2007年 9 月30日) (http://www.my 
newsjapan.com/reports/695）（2012年 5 月 4 日取得）。

山本英弘 (2010)「利益団体の影響力——多角的な視点からみる権力構造」 辻中豊・森裕城編著『現代社会集団の政治機能一一利益団体と市民社会』 木鐸社, $237-252$ 頁。

読売新聞社会部（2003）『ヤミ金融』中央公論新社。 